\title{
KONSTRUOWANIE OBRAZÓW RZECZYWISTOŚCI W AKCIE USTAWODAWCZYM
}

\author{
Maria Teresa Lizisowa, Profesor \\ Uniwersytet Papieski Jana Pawła II w Krakowie \\ ul. Wita Stwosza 55, 80-952 Gdańsk \\ lizis@tlen.pl
}

\begin{abstract}
Abstrakt: Artykuł prezentuje przedmiotowość wytworów semantycznych języka prawnego jako obrazów rzeczywistości w akcie ustawodawczym. W aspekcie semantyczno-pragmatycznym autorka analizuje treść znaczeniową i funkcję komunikacyjną znaków językowych ze względu na technikę wyrażania ich treści w przepisach prawnych. Analiza struktur gramatycznych i stylu tekstu prawnego wykazała, na czym polega sztuczność odniesień terminów, określeń i konstrukcji składniowych służących obrazowaniu przyczyny i skutku w wyrażeniach charakterystycznych dla języka prawnego, rozumianych nie wprost, czyli przekazujących implikowane treści niedosłownie.

Słowa klucze: język prawny, tekst prawny, przepis prawny, termin prawny, określenie prawne, funkcje znaków językowych, obrazy rzeczywistości prawnej, abstrakcyjny obraz normy prawnej.
\end{abstract}

\section{CREATING IMAGES OF REALITY IN STATUTORY INSTRUMENTS}

\begin{abstract}
The article presents the subjectivity of semantic signs of the legislative language as images of reality in a statutory instrument. The author presents a semantic and pragmatic analysis of the meaning and communicative function of language signs taking into account the techniques of expressing meanings in legal provisions. The analysis of grammatical structures and style of statutory instruments reveals the artificiality of references of terms, attributes and syntactical structures expressing cause and effect relations in expressions typical of the legislative language and conveying connoted messaged in a non-verbatim way.
\end{abstract}

Słowa klucze: język prawny, tekst prawny, przepis prawny, termin prawny, określenie prawne, funkcje znaków językowych, obrazy rzeczywistości prawnej, abstrakcyjny obraz normy prawnej. Key words: legislative language, statutory instrument, statute, legal term, legal attributes, function of language signs, images of legal reality, abstract imagage of a legal norm

\section{Wstęp}

W tradycyjnym językoznawstwie strukturalistycznym język złożony z systemu znaków oraz rządzących znakami reguł gramatycznych jest pojmowany przedmiotowo jako system. W ujęciu semantyczno-pragmatycznym system i mowę traktuje się całościowo w działaniach językowych jako zjawisko społeczne. Znaki języka w obrębie życia społecznego przedstawiają celowe i racjonalne zachowania językowego człowieka. W artykule podejmuję kwestię zewnętrznej refleksji nad językiem aktów ustawodawczych. Analiza ma na celu przedstawienie strategii użycia znaków językowych o treści prawnej oraz poznanie zasad pozwalających na konstruowanie obrazów przyczyny i skutku w strukturach zdań podrzędnie złożonych warunkowych, charakterystycznych dla wypowiedzi ustawodawcy. 


\section{Przedmiotowość wytworów semantycznych języka}

Bronisław Wróblewski określił język prawny jako swoisty język przedmiotowy ustawodawcy ze względu na przedmiot odniesienia znaków tego języka do materii prawa i przypisywanie znakom języka etnicznego znaczeń prawnych i prawniczych ${ }^{1}$. Zakładał, że wytworem semantycznym języka jest każdy znak - wyrażenie i związane z wyrażeniem pojęcie - występujący w danym języku przedmiotowym w obrębie różnych sytuacji. Tak więc wytworami semantycznymi języka są znaki językowe w postaci wyrazów układanych w zdania. Znaki te służą do powiadamiania siebie i innych o treści myśli. Znak językowy znaczy swe znaczenie w danym języku przedmiotowym grupy osób (polilekcie), natomiast wyraża znaczenie psychologiczne w języku podmiotowym danej osoby (idiolekcie). Dany język przedmiotowy wyróżnia się na tle innych swoistych języków przedmiotowych przede wszystkim znaczeniem wyrazów.

W języku przedmiotowym - pisał uczony - mamy do czynienia z różnymi odniesieniami słów do tej samej mowy etnicznej. Ten sam wyraz w różnych językach może odnosić się do czegoś innego. Przedmiotem wytworów semantycznych języka prawnego jest konwencjonalne i profesjonalne znaczenie słów języka ogólnego.

Przedmiotowość wytworów semantycznych języka prawnego mieści się w płaszczyźnie tworzywa ustawodawczego, bowiem język prawny nie jest językiem rzeczywistości prawnej, lecz realizacją języka prawnego są przepisy prawne zamieszczone w tekście prawnym. W świecie tekstu prawnego konstruuje zatem ustawodawca tworzeniem swoistych znaczeń słów i zdań obrazy rzeczywistości abstrakcyjnej ${ }^{2}$. Rzeczywistością tą są normy prawne ustanowione przez kompetentnego ustawodawcę i obowiązujące poddanych jego władzy ustawodawczej. Odbiorca tekstu prawnego odczytuje normy prawne, interpretując zawarte w tekście prawnym przepisy prawne. Natomiast materiał, który reglamentuje ustawodawca albo jest konstruowany przez ustawodawcę jako to, co w przyszłości będzie się działo pod znakiem powinności, albo to, co istnieje w życiu prawnym, czyli w określonej rzeczywistości prawnej i w poczuciu prawnym społeczeństwa.

Wytwory semantyczne w postaci przede wszystkim wyrazów jako nosicieli znaczeń językowych związanych z czynnościami mownymi człowieka, zwłaszcza z pojmowaniem myślowym, są budulcem języka. Chcąc posługiwać się językiem prawnym musimy poznać jego aparaturę pojęciową i słownictwo. Słowa nabierają znaczeń w sąsiedztwie innych słów, z czego wynika, że ustalenie znaczeń wyrazów

\footnotetext{
${ }^{1}$ Twórca terminów język prawny i język prawniczy wyróżnił język prawny ustawodawcy oraz języki prawnicze prawników zawodowych i prawoznawców na tle innych języków przedmiotowych, takich jak naukowy, filozoficzny, techniczny, techniki społecznej, a także w opozycji do języków zawodowych i środowiskowych, zob. Wróblewski 1948: 54-56.

2 Tekstami języka prawnego są akty normatywne. Przepisy prawne wyrażeniami języka prawnego, zob. Malinowski 2006:30. W tekście prawnym legislator posługuje się pojęciem przepis prawny, nie zaś konstrukcją norma prawna. W prawoznawstwie rozróżnienie przepisu prawnego i normy prawnej przybierało różne postacie, zob. Ziembiński 1960: 105, Zieliński 2002: 16 i n. Maciej Zieliński przyjmuje, że przepis prawny to zdanie w sensie gramatycznym (od kropki do kropki) wyraźnie wyróżnione graficznie w tekście prawnym i oznaczone w nim zwykle jako artykuł czy ustęp lub fragment artykułu lub ustępu.
} 


\section{Comparative Legilinguistics 17/2014}

następuje przy pomocy zdań, w których są używane. Zdanie jest więc drugim istotnym wytworem semantycznym języka.

Postać wyrażeń języka przybierają wypowiedziane pojęcia i sądy. Pojęcia i sądy będące jądrami znaczeniowymi wyrażeń są wytworami semantycznymi ludzkiego umysłu - urzeczywistniają się w formie powszechności, są bowiem wynikiem opracowania myślowego wyobrażeń wielu przedmiotów uważanych za podobne ${ }^{3}$.

\section{Znak językowy i jego znaczenie w języku prawnym}

Ze stanowiska semiologii przedmiotem badań języka są znaki. Ferdinand de Saussure przyjął, że znak jest konwencjonalnym związkiem formy materialnej i treści mentalnej, który funkcjonuje w procesie komunikowania jako samoistna jakość, oderwana od rzeczywistości. Uczony ten zakładał, że znak językowy łączy nie rzecz i nazwę, lecz obraz akustyczny jako formę materialną i pojęcie jako treść mentalną. Stosunek nazwy do rzeczy, czyli znaku językowego do rzeczywistości pozajęzykowej, jest nową relacją, która polega na przypisywaniu przedmiotom, obiektom lub zjawiskom treści mentalnych ${ }^{4}$. W tym odniesieniu treść znaczona utożsamia się z treścią przedmiotu, albo jest różna od treści przedmiotu.

Charles S. Perice uznał, że znak będący środkiem przekazu, przedmiot jako obiekt istniejący realnie bądź intencjonalnie w czyjejś wyobraźni, jak również interpretant wiążący znaczeniowo środek przekazu z przedmiotem i wnoszący określoną treść, tworzą związek trójczłonowy. Interpretant nie jest podmiotem interpretującym, lecz innym znakiem, który łączy materialną formę pierwszego znaku z przedmiotem, nadając znaczenie tak znakowi, jak i przedmiotowi, oraz przypisując obu określoną treść pojęciową, podczas kiedy wszystkie te znaki i ich interpretenty reprezentują ten sam przedmiot. Według Hanny Buczyńskiej-Garewicz znaki pozostają w układzie systemu znaków. W systemie znaków każdy znak może być interpretowany przez wiele znaków należących do wielu kodów, w których może on reprezentować inne swoje właściwości lub funkcje. Człowiek może poznać dany przedmiot w procesie kodowania i dekodowania przekazu o tyle, o ile rozumie, jak można przełożyć dany znak na inne znaki ${ }^{5}$.

Syntetyczne ujęcie teorii de Saussure'a i Peirce'a w sposób zmodyfikowany przedstawia trójkąt semiotyczny Charlesa Kaya Ogdena i Ivora Armstronga Richardsa. W trójkącie semiotycznym znak to obiekt materialny, znaczenie to treść pojęciowa, odniesienie to obiekt realnie istniejący w rzeczywistości fizycznej lub społecznej, bądź obiekt istniejący tylko w sferze innych znaków i ludzkich wyobrażeń ${ }^{6}$. Zdzisław Wąsik przyjmuje, że znak i jego przedmiot odniesienia tworzą oddzielne jednostki w rzeczywistości mentalnej i konkretnej oraz oddzielne relacje między tymi jednostkami. Wynika to z definicji znaku Pierre'a Guirauda, że znak jako substancja zmysłowa jest bodźcem, którego obraz myślowy człowiek kojarzy z obrazem innego bodźca i którego funkcją jest wywołanie następnego bodźca ${ }^{7}$. Znaczenie w perspektywie

\footnotetext{
${ }^{3}$ Zob. Wróblewski 1948: 13-14.

${ }^{4}$ Istota znaku językowego jako signifié i signifiant, zob. Saussure 1961: 89-94.

${ }^{5}$ Znak jako środek przekazu, zob. Peirce 1931, por. Buczyńska-Garewicz 1980.

${ }^{6}$ Zob. trójkąt oznaczania: Ogden i Richards 1923.

${ }^{7}$ Zob. Wąsik1997: 136. Autor twierdzi, że znak jest jednością czteroelementową lub siecią relacji między czterema elementami: „(1) znak jako bodziec, (2) obraz mentalny znaku jako bodźca, (3)
} 
Maria Teresa Lizisowa, Kreowanie obrazów rzeczywistości w akcie ustawodawczym

znakowo-komunikacyjnej należałoby więc wyprowadzać - według Z. Wąsika „z relacji między wyrażeniem strony oznaczającej a oznaczaną treścią, czy między wyrażeniem strony oznaczającej a oznaczaną funkcją, czy też między wyrażeniem strony oznaczającej a oznaczaną wartością obiektów subsumowanych do przedmiotów należących do domeny semiotyki",

Konstruowanie obrazów świata tekstu w akcie ustawodawczym przebiega zatem w płaszczyźnie znaku i znaczenia. Mieczysław Albert Krąpiec stwierdził, że poznanie pojęciowe jest znakiem formalnym, naturalnym, natomiast język jako mowa, pismo lub gesty to znaki instrumentalne, konwencjonalne. Pojęcia i sądy są więc znakami naturalnymi, znakami konwencjonalnymi są wyrazy i zdania. Na podstawie obu typów znaków dokonuje się poznanie i komunikowanie drugiemu treści związanych $\mathrm{z}$ bytem i przedstawionych $\mathrm{w}$ samym znaku, czyli ujęte selektywnie znaczenie 9 .

Mówiąc o znakach języka prawnego, szukamy ich odniesień nie do rzeczywistości prawnej, lecz do świata tekstu prawnego. Znaczenie i odniesienie znaków językowych jest tworem ustawodawcy i odbiorcy tekstu ustawodawczego a pojęciowa treść znaku jako uogólniony zbiór doznań, wrażeń i wyobrażeń powstaje w umyśle człowieka pod wpływem podobnych bodźców. Pojęcia prawne istnieją tylko w ludzkiej świadomości - poza świadomością pojęcie „może być wyrażone tylko za pomocą znaku, a jego treść może być wyjaśniona tylko za pomocą innych znaków"10.

Jeżeli zajmujemy się konstruowaniem obrazów w akcie ustawodawczym, należy dodać, że konwencjonalne znaki symboliczne języka mogą być proste i złożone. Tak więc w języku prawnym (1) bodźcem są znaki językowe, czyli słowa, zdania czy teksty, które wywołują (2) obrazy mentalne znaku jako bodźca w wyobrażeniach nadawcy i odbiorcy odnośnie słów, zdań czy tekstu prawnego, jak również (3) obrazy mentalne przedmiotu odniesienia znaku jako inny bodziec, czyli treści pojęć prawnych, sądów normatywnych czy całych aktów normatywnych, jak również (4) przedmioty odniesienia znaków, czyli osoby prawne i ich postępowanie oraz przedmioty regulacji prawnych rozpoznawane pod znakiem powinności.

Analiza znaku wyjaśnia fakt poznawczego porozumiewania się ustawodawcy z odbiorcami tekstu prawnego. Jeżeli zatem przyjmiemy za Mieczysławem Krąpcem, że treść znaczona albo utożsamia się z treścią przedmiotu, albo różni się od treści samego

obraz mentalny przedmiotu odniesienia znaku jako innego bodźca (4) przedmiot odniesienia znaku jako inny bodziec".

${ }^{8}$ Zob. też Wąsik 1997: 149. Dokonując przeglądu koncepcji znaków, autor przedstawił typologię znaków i ich pochodnych według ich statusu ontologicznego i form manifestacji.

${ }^{9} \mathrm{~W}$ znaku instrumentalnym istnieją wszystkie momenty znakowania: podmiot poznający ewentualnie ustanawiający znak, przedmiot poznania i treść znaku. Treść znaku jest inna w różnym stopniu od treści przedmiotowej (bytowej) przez znak wskazywanej. Zagadnienie znaku otwiera rozumienie języka w kondycji ludzkiej własności, tkwiące w zasadniczym jego charakterze - symbolicznym. Poznanie świata jest określone ekspresją mowy, bez której nie może istnieć myślenie. Zob. Krąpiec 1985: 30-39.

${ }_{10}$ Podobnie analizę znaków w tekstach prasowych przedstawia Maciej Mrozowski, zob. Mrozowski : 2002: 278.

14 


\section{Comparative Legilinguistics 17/2014}

przedmiotu $^{11}$, jak również weźmiemy pod uwagę za Karlem Bűhlerem, że znak językowy w postaci konkretnego zjawiska dźwiękowego czy zapisu jest symbolem na mocy swojego przyporządkowania do przedmiotów i stanów rzeczy oraz do treści znaczonej, to zakładamy także, iż znak ten zostaje zawsze uzupełniony przez percepcję na mocy swojego związku z nadawcą jako sygnał stanowiący apel do odbiorcy, którego zachowaniem steruje $\mathrm{e}^{12}$.

\section{Treść znaczeniowa a funkcja komunikacyjna znaków językowych}

O rzeczywistości prawnej mówi się językiem codziennym (powszechnym) z dodaniem - jak to określił Wróblewski - pewnego rodzaju gwary prawnej, jak również swoistym językiem przedmiotowym tej dziedziny życia społecznego, która w ustawie jest normowana. $\mathrm{Z}$ tego materiału językowego czerpie ustawodawca, nadając swojej wypowiedzi w formie przepisów prawnych składających się na teksty prawne sformułowania według zasad techniki języka prawnego. Zob. schemat 1.

Schemat 1. Odmiany języka w tekstach prawnych.

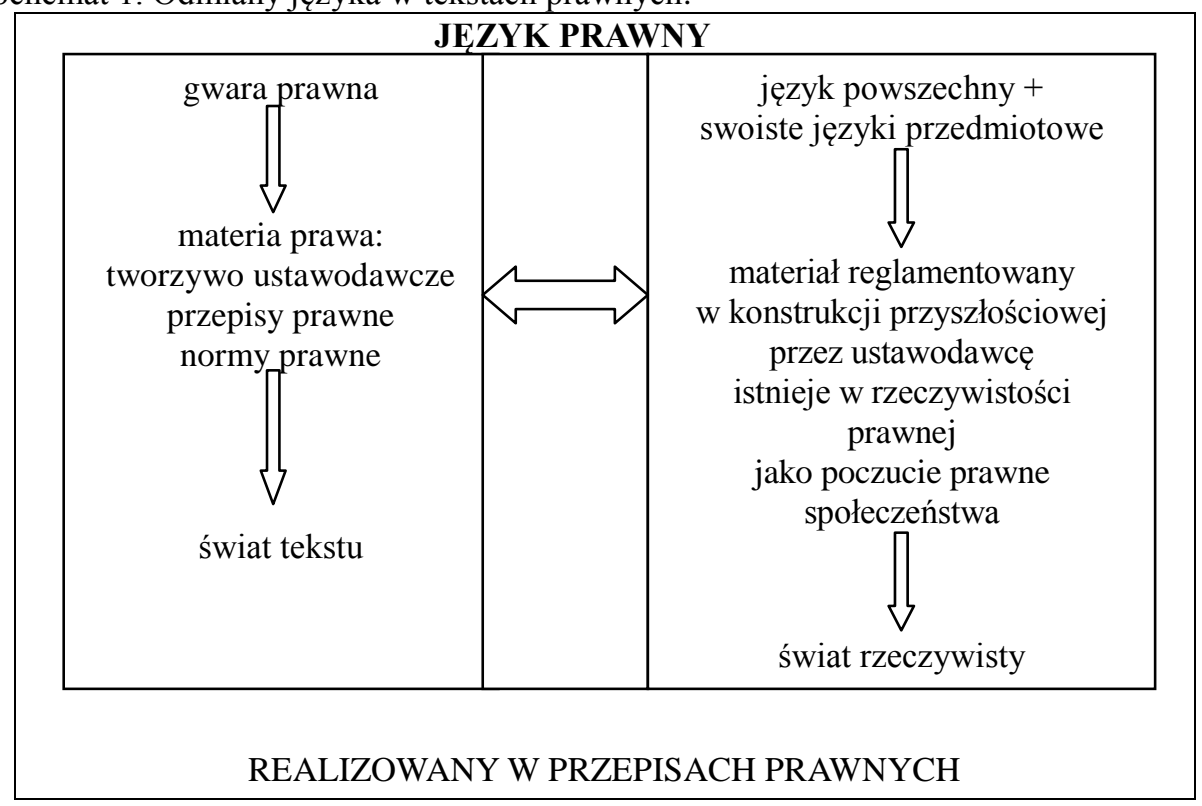

Czynnikiem decydującym o treści znaczeniowej wyrażeń jest funkcja komunikacyjna. $\mathrm{W}$ różnych językach następuje sczepienie (podpinanie) materiału, który odtwarza treść pojęcia. Tak więc na przykład pojęcie PREZES ZARZĄDU BANKU PAŃSTWOWEGO jest treścią nie tylko prawa, lecz wiąże się bezpośrednio z bankowością. $\mathrm{W}$ związku z tym inaczej przedstawia się to pojęcie dla pracowników banku, inaczej dla ustawodawcy i prawnika. Nie w każdej bowiem wypowiedzi wyrażenie językowe

\footnotetext{
${ }^{11}$ Por. treść znaczona a treść przedmiotu: Krąpiec 1985: 34.

${ }^{12}$ Model języka jako narzędzia komunikacji, zob. Bühler 2004: 29.
} 
Maria Teresa Lizisowa, Kreowanie obrazów rzeczywistości w akcie ustawodawczym

stanowi odpowiednik pojęcia. Na przykład wyrażenie prezes zarządu banku ma wiele odniesień w różnych kontekstach. W zdaniu Widzę prezesa zarządu banku - to konkretna osoba (np. Jan Kowalski) sprawująca funkcję osoby reprezentującej bank; w zdaniu Trzeba koniecznie powołać prezesa zarzadu banku - to w interpretacji powszechnej tego znaku wyobrażenie potoczne; w zdaniu Prezes zarzadu banku państwowego jest wedtug postanowień statutowych zwierzchnikiem zarządu banku - to pojęcie bankowców; w zdaniu Prezes zarządu banku państwowego reprezentuje bank (art. 18. pkt. 4. ustawy prawo bankowe) - to wyobrażenie prawne; w zdaniu Prezes zarzadu banku państwowego jest adresatem normy prawnej ustanowionej przepisem art, 18. pkt. 4. ustawy prawo bankowe - to pojęcie prawnicze.

Ze stanowiska teoretycznego aparat pojęciowy, do którego odnoszą znaki języka prawnego - pisał B. Wróblewski - ma charakter półfabrykatów, którym w interpretacji należy nadać właściwy sens. Ustawodawca czerpie materiał językowy $\mathrm{z}$ różnych języków przedmiotowych, nadając im sens prawny. W metajęzyku interpretacji prawniczej prawnicy czerpią z języka prawnego składniki semantyczne, a także tworzą własny aparat pojęciowy. Wytwórczość językowa prawnika-praktyka (jurysprudencja) ma miejsce wtedy, kiedy ustawodawca milczy lub wypowiada się w sposób niedostateczny. Teoretyczna twórczość pojęciowa prawników ma na celu poznanie aparatu pojęciowego ustawodawcy i wydanych przez niego ustaw.

W języku prawnym znaczenie wyrażeń powiązanych w całość przedmiotową oznacza, że ludzie posługujący się tym językiem reagują w taki sam sposób poznawczy $\mathrm{i}$ emocjonalny na jego znaki ${ }^{13}$. Język prawny zwarty $\mathrm{w}$ tekstach ustawodawczych oraz języki prawnicze - nauki prawa i praktycznej interpretacji tekstów prawnych wzajemnie na siebie oddziałują, mimo że ich składniki semantyczne są różne. To świadczy, że wyobrażeniom prawnym jako półfabrykatom semantycznym języka prawnego w wykładni prawniczej można nadać znaczenie prawnicze przez odniesienie do odpowiedniego pojęcia prawniczego.

\section{Technika i styl języka prawnego}

Cel użycia wyrażeń decyduje o prawidłach używania języka. W użyciu języka formułuje się jego przedmiotową stronę poprzez technikę wyrażania i styl. Celowe użycie znaków językowych wymaga odpowiedniej techniki językowej, która ma wyrazić stosunek - podrzędny czy nadrzędny - pomiędzy wypowiadającym się a słuchającym oraz powinna okazać, z jaką reakcją ma łączyć się rozumienie wypowiedzi, aby być lepiej zrozumianym. Wynikiem zastosowania techniki językowej przez ustawodawcę jest konstruowanie drogą dedukcji pojęć na podstawie danego materiału językowego w konwencjonalnej formie stylistycznej. Celom komunikacyjnym podporządkowane jest tworzywo ustawodawcze najbardziej odpowiadające porozumieniu się ustawodawcy z osobami, dla których odpowiednie przepisy prawne są stanowione, w sprawie ich postępowania.

Tworzywo ustawodawcze - to słowa odnoszące do wyobrażeń i pojęć prawnych, zdania normatywne wyrażające sens prawny, obudowane zdaniami

\footnotetext{
13 Znaczenie wyrażeń w języku prawnym jako użycie wyrażeń języka, zob. Wróblewski 1948: 11. 16
} 


\section{Comparative Legilinguistics 17/2014}

opisowymi i wraz ze zdaniami normatywnymi wchodzącymi w skład przepisów prawnych, z których składają się teksty prawne ${ }^{14}$.

Słowa, będące wytworami semantycznymi języka prawnego, mają sztuczne znaczenie w stosunku do słów języka ogólnego. Znaczenie słów staje się wytworem semantycznym języka prawnego przez użycie ich w przepisach prawnych, gdzie ich znaczenie tekstowe jest inne niż w pozostałych swoistych językach przedmiotowych. Słowa, które w języku prawnym mają znaczenie konwencjonalne i profesjonalne, odnoszą się do materiału reglamentowanego przez ustawodawcę.

Materiał reglamentowany przez ustawodawcę (1) jest abstrakcyjnie konstruowany pod znakiem powinności jako normy prawne; (2) istnieje faktycznie w życiu prawnym przez zastosowanie norm prawnych w życiu społecznym - albo w rzeczywistości prawnej, albo w poczuciu prawnym społeczeństwa. Materiał abstrakcyjnie konstruowany to stosunki prawne tetyczne, a materiał empiryczny w życiu prawnym to stosunki prawne rzeczywiste.

Użyte w charakterze nazw słowa mogą być odnoszone do wyobrażeń konkretnego przedmiotu, czynności czy stanu rzeczy. Dzięki odpowiednim zabiegom technicznym, w tekście prawnym może też nastąpić uściślenie znaczenia słowa, które staje się terminem jako symbol pojęcia prawnego lub nazwą techniczną będącą symbolem wyobrażenia prawnego. Uściślenie znaczenia słowa następuje $\mathrm{w}$ definicjach legalnych, albo jest modelowane kontekstowo dzięki technice tworzenia zdań normatywnych.

Pojęcia prawne są zdefiniowane w przepisach prawnych przez samego ustawodawcę. Legislator formułuje ich definicje objaśniające znaczenie, które zamieszcza w tekście aktu prawnego. Posługiwanie się definicjami zapobiega wieloznaczności i niedookreśloności wyrazów użytych w ustawie. Definiowane terminy techniczne zachowują tylko takie znaczenie, jakie zostało ustalone w definicji. Zamieszczenie definicji w tekście aktu prawnego przesądza o uznaniu jej za definicję legalną. Zaś zamieszczenie definicji legalnej w takim tekście nadaje jej charakter normatywny ${ }^{15}$.

Abstrakcyjne pojęcia prawne często są niezdatne do definiowania w tekście prawnym - definiowanie pojęć, takich jak adresat normy prawnej, recipient działania nakazanego w normie prawnej, czy przedmiot regulacji prawnej, jest sprawą nauk prawnych.

Przypisywanie znakom językowym reprezentacji określonych obiektów, sytuacji bądź wyobrażeń w sposób obiektywny określa się terminem lingwistycznym denotacja. Gdy ten sam znak jest używany w różnych językach przedmiotowych i w różnych sytuacjach społecznych - pisze Maciej Mrozowski - obrasta on konotacjami składającymi się na jego treść pojęciową. Przy każdym użyciu znaku konotacje aktualizują się w zależności od kontekstu i od tego, kto o czym i jak mówi. Ponadto znak ,narzuca pewien sposób myślenia i interpretowania nie tylko o tym, do

\footnotetext{
${ }^{14}$ Przepisy prawne składają się ze zdań normatywnych i zdań opisowych. Centrum przepisu prawnego jest zdanie normatywne. Zdania opisowe stanowią obudowę zdań normatywnych. Szerzej na temat gramatycznych i składniowych wykładnikach stylu języka prawnego, zob. Lizisowa 2006: 58-64.

${ }^{15}$ Szerzej na temat definicji legalnych, zob. Wronkowska 2007: 15, zob. też Malinowski 2006: 155-157.
} 
czego się bezpośrednio odnosi, ale także o całym zjawisku, instytucji czy sytuacji, której częścią jest to odniesienie. Zatem materialna forma znaku wskazuje na obszar znaczeń jasno i jednoznacznie zdefiniowany w polu denotacji na pierwszym poziomie znaczenia. W polu konotacji pojęcia mają płynny kształt i mogą obejmować sprzeczne skojarzenia na drugim poziomie znaczenia. Na trzecim poziomie znaczenia powstają mity, które nakładają się na dwa poprzednie poziomy znaczeń - tu znaczenie jest ogólniejsze niż denotacja oraz bardziej nacechowane emocjonalnie, silniejsze i bardziej jednoznaczne niż konotacja. Tylko osoby o dobrej kompetencji komunikacyjnej mogą interpretować rzeczywistość konstruowaną przez ustawodawcę na wszystkich trzech poziomach znaczeń poprzez znaki w odniesieniu do obiektów konkretnych, jak i abstrakcyjnych ${ }^{16}$.

Zdania normatywne charakteryzują się tym, że ich predykaty są zwrotami powinnościowymi. Mogą występować w tekście prawnym jako zdania pojedyncze rozwinięte, np.:

Art. 109. § 1. Udzielenie i wygaśnięcie prokury przedsiębiorca powinien zgłosić do rejestru przedsiębiorców.

Art. 109. Prokurent składa własnoręczny podpis zgodnie ze znajdującym się w aktach rejestrowych wzorem podpisu...

[Kodeks cywilny]

Zdania te są twierdzeniami normatywnymi bezpośrednio i kategorycznie ustanawiającymi normy prawne. Są więc znakami norm prawnych. Części zdania normatywnego wskazują adresata normy i orzekają o powinności jego postępowania ze względu na recipienta działania nakazanego przez tę normę oraz na przedmiot regulacji prawnej.

Orzekanie w języku prawnym konstruuje pojęcia modalności prawnych $\mathrm{w}$ formie orzeczeń modalnych lub czasownikowych ${ }^{17}$. Wskazywanie adresata normy prawnej i dopełnianie orzekania o przedmiot regulacji prawnej i o recipienta wiążą się z wyobrażeniami prawnymi.

Analiza semantyczno-pragmatyczna zdań normatywnych i ich elementów jako znaków sądów i pojęć prawnych polega na wykazaniu ich sczepienia z pojęciami i sądami w innych domenach życia społecznego. Na szczególną uwagę zasługują składniki semantyczne argumentów i predykatów w głównym zdaniu przepisu prawnego, które jest zdaniem dyspozycyjnym - normatywnym. Rolą ustawodawcy jest nadanie znakom języka etnicznego - także predykatom - sensu prawnego. Wytworem języka prawnego jest to, co jest sztuczne w odmianie powszechnej języka etnicznego. Zdanie normatywne ma ściśle określone składniki, czyli predykat modalny oraz trzy argumenty: podmiot i dopełnienie dalsze to argumenty podmiotowe, dopełnienie bliższe to argument przedmiotowy.

\footnotetext{
${ }^{16}$ Obszary i poziomy znaczeń w użyciu języka, zob. Mrozowski 2001: 278-284.

${ }^{17}$ Zdania z orzeczeniami czasownikowymi mają gramatyczną formę opisową - z perspektywy pragmatycznej są twierdzeniami normatywnymi, bowiem orzekają modalności prawne, komunikując faktycznie kompetencje ustawodawcze nadawcy. W orzeczeniach modalnych modalizatory wskazują na przykład: powinien / może - powinność; ma prawo - należność. 


\section{Comparative Legilinguistics 17/2014}

Przyjmuję zatem, że analiza znaczenia znaków językowych w języku prawnym sprowadza się do przekładania znaku języka na inne znaki, co w gruncie rzeczy jest interpretacją tego znaku w metajęzyku. Odnoszenie znaków jest więc konotowaniem obrazów pewnej rzeczywistości pozajęzykowej. Jeżeli przyjmiemy za B. Wróblewskim słuszną zasadę, że w języku prawnym obraz rzeczywistości nie przedstawia rzeczywistości prawnej, to należy z kolei przyjąć, że przepisy prawne konstruowane pod znakiem powinności odnoszą się do rzeczywistości postulowanej, a odniesienie to $\mathrm{w}$ polu denotacji ma charakter sztuczny. W polu konotacji konkretna osoba w konkretnej sytuacji uwzględnia różne, nawet sprzeczne, kojarzenia. Natomiast od kompetencji komunikacyjnej odbiorcy jest uzależnione przypisywanie odniesienia w polu mitów ${ }^{18}$.

\section{Sztuczne znaczenie słów w przepisach prawnych}

Przykład odniesienia znaku językowego prezes zarządu banku państwowego w interpretacji nauki i w interpretacji powszechnej ilustruje źródło czerpania materiału językowego użytego w przepisie prawnym, w którym znak języka ogólnego lub fachowego przybiera sztucznie znaczenie prawne.

Jeżeli w zdaniu normatywnym znak językowy jest pierwszym argumentem (podmiotem), znak ten wskazuje adresata wypowiedzi (prezes zarzadu banku państwowego), zobowiązanego do danego działania wobec przedmiotu działania (bank), będącego drugim argumentem w tym zdaniu (dopełnieniem bliższym), np.

Prezes zarządu banku państwowego $\left(\mathrm{A}_{1}\right)$ reprezentuje bank ...

[art. 18 pkt. 4 ustawy prawo bankowe]

Jeżeli znak językowy jest drugim argumentem w zdaniu normatywnym, znak ten odnosi się do recipienta działania nakazanego innej osobie, któremu to działaniu dana osoba podlega, np.

Prezesa zarządu banku państwowego $\left(\mathrm{A}_{2}\right)$ powołuje i odwołuje [...] rada nadzorcza banku $\left(\mathrm{A}_{1}\right)$

[art. 17 ustawy prawo bankowe]

W jednym przepisie prawnym prezes banku to adresat normy prawnej, w innym to recipient działania nakazanego tym właśnie przepisem. Uogólniając, dochodzimy do wniosku, że ustawodawca tak konstruuje tekst przepisu prawnego, aby wyrazić w nim pojęcia języka prawniczego (adresat normy prawnej $A_{1}$ - recipient działania nakazanego

\footnotetext{
${ }^{18}$ Pojęcie i termin mit wprowadził francuski teoretyk semiologii, Roland Barthes. Opracował on model przedstawiający wpływ znaków i kodów na postrzeganie i interpretowanie rzeczywistości przez jednostki. W modelu tym przedstawił dwa porządki funkcjonowania przekazu. W pierwszym porządku znajduje się fizyczna reprezentacja znaku i jego element znaczony, w drugim zaś, osadzonym w kulturze, ma miejsce konotacja i mit. Mit nie oznacza tutaj nieprawdziwej historii, tylko skomplikowane konstrukty tłumaczące i naturalizujące w danych kulturach pewne aspekty rzeczywistości, zob. Barthes 2000.
} 
Maria Teresa Lizisowa, Kreowanie obrazów rzeczywistości w akcie ustawodawczym

w normie prawnej $\mathrm{A}_{2}$ ) - nie używając terminów wypracowanych w teorii prawa, lecz posługując się słownictwem języka powszechnego.

Sztuczne znaczenie mają też składniki semantyczne nazw przedmiotów regulacji prawnej, które $\mathrm{w}$ zdaniach normatywnych pełnią funkcję argumentów rzeczowych, abstrakcyjnych, o czym świadczy na przykład termin prawny domniemanie.

W języku powszechnym mamy słowa domniemywać się i domniemanie: domniemywać się czegoś oznacza, iż można przypuszczać, że tak właśnie jest, jak nam się wydaje, chociaż nie mamy pewności. Fakt domniemania jest całkowicie możliwy, w codziennym doświadczeniu możemy ten fakt potwierdzić. Opieramy się wówczas na związkach empirycznych, dla których przesłankami są objawy i symptomy, a na ich podstawie wnioskujemy o faktach, np. mamy domniemanie (domniemywa się), że Anna jest poważnie chora, bo często chodzi do lekarza.

Inaczej przebiega wnioskowanie według art.7 Kodeksu zobowiązań. Wnioskowanie ustawodawcy nie opiera się na faktach, nie ustala związku empirycznego pomiędzy warunkami faktycznymi a skutkami prawnymi, por. tekst:

Art. 7. $§ 1$. Dłużnik, który wykonał zobowiązanie niepodzielne, może żądać od spółdłużników zwrotu wartości świadczenia w części, jaka na każdego z nich przypada.

$\S 2$. Wierzyciel, który otrzymał świadczenie niepodzielne, jest odpowiedzialny w stosunku do współwierzycieli w częściach, które na nich przypadają.

§ 3. Domniemywa się, że części są równe.

(Kodeks zobowiązań)

Ustawodawca słowem domniemywa się ustanawia, że część świadczeń, jakich może żądać dłużnik od współdłużników i w jakich wierzyciel jest odpowiedzialny w stosunku do współwierzycieli, a sąd czy inny organ kompetentny, rozstrzygający ewentualny spór w sprawie zwrotu wartości świadczenia dłużnika od współdłużników w częściach, jak również odpowiedzialności wierzyciela w stosunku do współwierzycieli w częściach, powinien przyjąć w rozstrzygnięciu sporu, że części te są równe.

Można przyjąć, że domniemanie w prawie nie ustala wniosku o fakcie, że są to swoiste związki pomiędzy warunkami faktycznymi a skutkami prawnymi. W domniemaniach prawnych normuje się, że empiryczne prawdopodobieństwo waha się pomiędzy praktyczną niemożliwością a praktyczną pewnością tego, co ustawodawca ustanawia - i tu jest miejsce dla wykładni prawniczej. Tak unormowane domniemanie funkcjonuje w innych przepisach prawnych jako termin prawny odnoszony do pojęcia przedmiotu regulacji prawnej, prawniczego jak i prawnego, np.:

Art. $222 \S 2$. Dobrowolny zwrot dokumentu lub zaznaczenie przez wierzyciela na dokumencie, że świadczenie zostało spełnione częściowo lub zmniejszone, uzasadnia domniemanie, że dług w całości lub w części został zapłacony, albo że dłużnik został w całości lub w części z długu zwolniony.

Art. 224. Piśmienne potwierdzenie odbioru kapitału uzasadnia domniemanie, że wszelkie należności dodatkowe, jako to odsetki i t. p., zostały zaspokojone.

(Kodeks zobowiązań) 


\section{Comparative Legilinguistics 17/2014}

Tu mamy związek między faktem opartym nie na doświadczeniu, lecz na wykładni prawniczej poprzez odniesienie terminu domniemanie do pojęcia DOMNIEMANIA na podstawie kontekstu.

\section{Obrazowanie modalności prawnych w zdaniach normatywnych}

Predykaty zdania dyspozycyjnego w przepisie prawnym kwalifikują czyn. Ponieważ w języku polskim czasowniki modalne są wieloznaczne, ustawodawca profiluje ich znaczenie, nadając im jednoznaczny sens normatywny. W zwrocie $A_{I}$ powinien czynić $P$ ustawodawca generalnie zakłada normatywność treści zdania dyspozycyjnego w przepisie prawnym - $\mathrm{i}$ jest to forma wyrażająca bezwzględny nakaz przy wyraźnym wskazaniu adresata $\mathrm{A}_{1}$ i przedmiotu $\mathrm{P}^{19}$, np. w Kodeksie cywilnym:

art. 161. § 2. Gdyby poszkodowany utracił w całości lub w części zdolność do pracy zarobkowej, albo gdyby zwiększyły się jego potrzeby lub zmniejszyły widoki powodzenia w przyszłości, zobowiązany do odszkodowania powinien mu wypłacać rentę w wysokości, odpowiadającej wyrządzonej szkodzie.

Formie opisowej czasownika $\mathrm{w}$ trybie oznajmującym $\mathrm{w}$ zwrotach $A_{l}$ czyni $P$ ustawodawca nadaje ewidentnie normatywne znaczenie nakazu orzeczeniem czasownikowym w zdaniach dyspozycyjnych, np.:

Art. 38. Osoba prawna działa przez swoje organy w sposób przewidziany w ustawie i w opartym na niej statucie.

Ze względu na sztuczne odniesienie predykatów w zdaniach dyspozycyjnych są one znakami języka prawnego dzięki temu, że ich składnikiem semantycznym jest normatywność. W innych zdaniach tekstu prawnego te same predykaty występują w znaczeniu naturalistycznym, a więc opisowym, i są znakami języka powszechnego, które z naturalnych względów znalazły się w tekście prawnym, np.:

Art. 76. Jeżeli strony zastrzegły w umowie, że określona czynność prawna między nimi powinna być dokonana w szczególnej formie, czynność ta dochodzi do skutku tylko przy zachowaniu zastrzeżonej formy [ k. c.].

Tu słowo powinna, występujące w zdaniu opisowym znaczy, że czynność prawna jest skuteczna pod pewnym warunkiem zastrzeżonym przez strony - nie ma tu nakazu, mowa jest tylko o warunkach, które należy spełnić.

W przepisach zezwalających na uchylenie danej normy, w przepisach zezwalających na uznanie normy poprzednio obowiązującej, także w ograniczaniu zakazu zastosowania innych norm lub w przepisach udzielających kompetencji spotyka się zwroty $A_{l}$ może czynić $P$, które są formą wiążącą $\mathrm{z}$ podmiotem udzielanie dozwolenia lub przyznają kompetencje, np.:

19 Jest to modelowa formuła, która w tekście prawnym może być zastąpiona innym, lecz równoznacznym znakiem powinności, np. ma obowiązek czy jest zobowiązany). Zob. Zieliński 1992: 84 . 
Art. 149. Właściciel gruntu może wejść na grunt sąsiedni w celu usunięcia zwieszających się z jego drzew gałęzi lub owoców. Właściciel sąsiedniego gruntu może jednak żądać naprawienia wynikłej stąd szkody.

W przepisach prawnych uprawniających do zachowania się innego podmiotu niż adresat $\mathrm{i}$ nakładających na ten drugi podmiot (czyli recipienta) obowiązek określonego zachowania się wobec podmiotu zobowiązanego ustawodawca używa zwrotu $A_{2}$ ma prawo do $P^{20}$, np.:

Art. 202. § 1. Wierzyciel ma prawo żądać od dłużnika świadczenia osobistego tylko w przypadkach, w których to wynika z umowy albo z natury zobowiązania [Kodeks cywilny].

Sztuczne znaczenie ma także czasownik posiłkowy jest. W zdaniu dyspozycyjnym przepisu prawnego znaczy to, co jest wskazane przez dany przepis prawny, a więc ma znaczenie prawne. To także sztuczne znaczenie, bo w języku ogólnym jest występuje jako łącznik $\mathrm{w}$ orzeczeniu imiennym lub $\mathrm{w}$ zdaniach egzystencjalnych znaczy to, że dany przedmiot istnieje. W języku prawnym przedmiot odniesienia czasownika jest to nie fakt istnienia, lecz fakt, że to, co jest wskazane przez ustawodawcę, wywołuje skutki prawne. Tak więc fakty, które nie zaistniały w rzeczywistości, są honorowane przez ustawodawcę. Mówi się wówczas, że przepis prawny oparty jest na fikcji, która jednak nie przeczy faktom, lecz jest swoistym skrótem charakterystycznym dla języka prawnego ${ }^{21}$.

Art. 43. Przedsiębiorcą jest osoba fizyczna, osoba prawna i jednostka organizacyjna, o której mowa $\mathrm{w}$ art. 3 . $\S 1$, prowadząca we własnym imieniu działalność gospodarczą lub zawodową. (k. c)

Znaczenie prawne czasownika jest $\mathrm{w}$ zdaniu normatywnym rzutuje na odpowiednie rozumienie faktu, zdarzenia czy stosunku w języku prawnym.

\section{Obrazy mentalne przyczyny i skutku w zdaniach warunkowych}

Jak pisał Bronisław Wróblewski, „technika języka prawnego posługuje się głównie zdaniami warunkowymi”, prototypowymi w języku prawnym. Częściej jednak w tekście prawnym są użyte takie zdania, które w interpretacji mogą być łatwo sprowadzone do zdań warunkowych po dokonaniu zmian redakcyjnych, jeżeli nie zmieniają ich sensu ${ }^{22}$. Zob. przykłady z Kodeksu cywilnego:

Art. 246. § 1. Jeżeli uprawniony zrzeka się ograniczonego prawa rzeczowego, prawo to wygasa. Oświadczenie o zrzeczeniu się prawa powinno być złożone właścicielowi rzeczy obciążonej.

\footnotetext{
${ }^{20}$ Klasyfikacja przepisów prawnych według: Zieliński 1992:120-122.

${ }^{21}$ Analiza jest $\mathrm{w}$ tekście prawnym, por. Wróblewski 1948: 59-60.

${ }^{22}$ Przykłady ilustrujące transformację zdań w interpretacji przepisu prawnego, zob. Wróblewski 1948: 89-90.
} 


\section{Comparative Legilinguistics 17/2014}

[Jeżeli prawo wygasa, oświadczenie o zrzeczeniu się prawa powinno być złożone właścicielowi rzeczy obciążonej.]

$\S 2$. Jednakże gdy ustawa nie stanowi inaczej, a prawo było ujawnione w księdze wieczystej, do jego wygaśnięcia potrzebne jest wykreślenie prawa z księgi wieczystej.

[Jednakże jeżeli ustawa nie stanowi inaczej, a prawo było ujawnione w księdze wieczystej, do jego wygaśnięcia potrzebne jest wykreślenie prawa z księgi wieczystej]

Art. 247. Ograniczone prawo rzeczowe wygasa, jeżeli przejdzie na właściciela rzeczy obciążonej albo jeżeli ten, komu prawo takie przysługuje, nabędzie własność rzeczy obciążonej.

Prototypowe zdania języka prawnego w terminologii gramatycznej nazywają się zdaniami podrzędnie złożonymi warunkowymi.

W analizie struktury zdań podrzędnych warunkowych uwzględnia się perspektywę czynnościową. Zdanie warunkowe dotyczy bowiem zachowania się osób, gdy te zachowania pociągają za sobą skutki prawne. B. Wróblewski pisal, że: „ustawodawca podaje w opisie tego lub innego wycinka rzeczywistości cechy lub stosunki, które posiadają znaczenie dla niego ze względu na sytuację prawną, do której wchodzi dany przedmiot [regulacji prawnej - dopisek MTL"] ${ }^{23}$.

Warto więc zauważyć, że zawartość opisów zmienia się w zależności od tego, na jakich przesłankach opiera się twierdzenie normatywne. W aspekcie przedmiotowym cechy wskazane w opisie dotyczą głównie czynności, np.: Jeżeli umowa została zawarta na cudzy rachunek... [art. $70 \S 1$. k. c.] W aspekcie podmiotowym ustawodawca uwzględnia również cechy związane z przeżyciami psychicznymi podmiotu prawnego, np.: Jeżeli uprawniony zrzeka się ograniczonego prawa rzeczowego... [art. 246. § 1. k. c.].

Dbałość o to, aby opis był zrozumiały dla każdego, wymusza z jednej strony używanie form potocznych wypowiedzi, np.: Jeżeli dziecko nie przebywa stale u żadnego z rodziców... [art. 26.§ 2. k.c.]. Z drugiej strony dbałość o precyzję wyrażania treści wymaga używania terminów, takich jak własność, rzecz obciażona itp., oraz wyrażeń i zwrotów języka prawnego, takich jak prawo przystuguje, nabędzie własność itp.; zob. przykład: jeżeli przejdzie na właściciela rzeczy obciążonej albo jeżeli ten, koти prawo takie przysługuje, nabędzie własność rzeczy obciążonej [art. 247. k.c.].

Inaczej przebiega obrazowanie w zdaniu nadrzędnym okresu warunkowego. Zdania nadrzędne mają charakter normatywny, np. Uprawniony zrzeka się ograniczonego prawa rzeczowego...; Ograniczone prawo rzeczowe wygasa. Znaki językowe jako predykaty zdań normatywnych, podobnie jak terminy i określenia prawne, nie mogą być potocznie rozumiane i zdefiniowane tylko w polu denotacji. Odnoszą się bowiem do obrazów mentalnych jako znaków konotujących w świadomości odbiorcy modalności prawne, ponieważ podlegają konkretyzacjom w kontekście reglamentowanego w danej dziedzinie prawa życia społecznego. Ich prawne znaczenia nakładają się na znaczenia w polach denotacji i konotacji, przyjmując

\footnotetext{
${ }^{23}$ Autor traktuje perspektywę opisu w tekstach prawnych globalnie, a więc także w zdaniach normatywnych, zob. Wróblewski 1948: 97-98.
} 
Maria Teresa Lizisowa, Kreowanie obrazów rzeczywistości w akcie ustawodawczym znaczenie najogólniejsze i nacechowane profesjonalnie. Ich odniesienie przypisuje się kompetencjom komunikacyjnym odbiorców i kulturowym aspektom odbioru.

Przepis prawny przedstawiony jako proces konkretnego wydarzenia mownego wraz z okolicznościami, w których to wydarzenie zachodzi, jest znakiem złożonym, charakterystycznym dla języka prawnego jako narzędzia komunikowania o danym zjawisku z perspektywy prawnej. Zob. schemat 2.

Schemat 2. Proces tworzenia wydarzenia mownego ustawodawcy

ETAP PIERWSZY

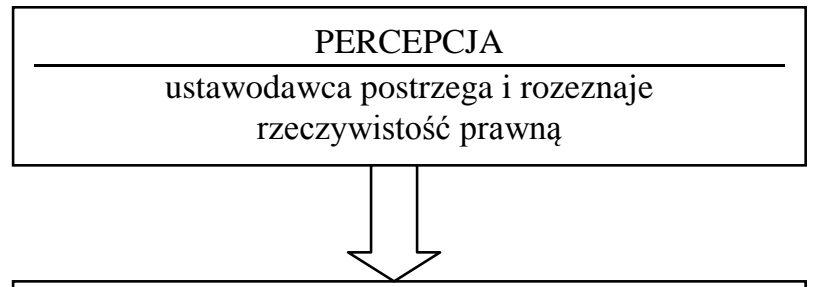

ETAP DRUGI

ETAP TRZECI

DZIAŁANIA MOWNE

ustawodawca nadaje przekaz rzeczywistości

abstrakcyjnej w postaci norm prawnych:

$>$ opisowo jako przyczynę działania

$>$ normatywnie jako skutek działania

$>$ ponadto przedstawia siebie oraz kreuje adresata, recipienta i przedmiot $w$ regulacji prawnej

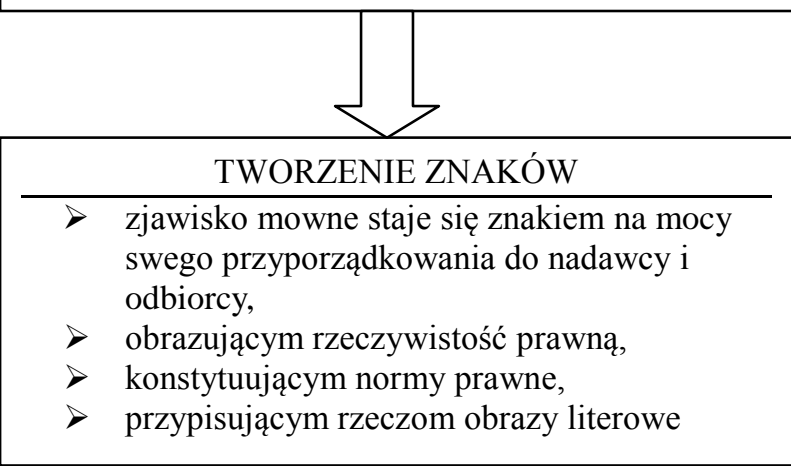

Proces ten przedstawia relacje przyczynowo-skutkowe w trzech etapach tworzenia wydarzenia mownego ustawodawcy. W pierwszym etapie ustawodawca percypuje rzeczywistość prawną (faktyczną lub postulowaną). Drugi etap odnosi się do działania mownego, w którym ustawodawca nadaje własny przekaz tej rzeczywistości, (1) opisowo obrazując zdaniem podrzędnym warunkowym lub jego ekwiwalentem tekstowym zespół warunków i okoliczności jako przyczynę wywołującą w sposób konieczny ustanowienie norm prawnych obowiązujących w życiu społecznym; (2) normy prawne ustanawia w postaci zdań normatywnych formujących nakazy, zakazy lub dozwolenia sterujące postępowaniem podmiotów prawnych jako skutek ich 


\section{Comparative Legilinguistics 17/2014}

działania, konstytuując obraz stosunków prawnych tetycznych; (3) nadawca przestawia siebie jako ustawodawcę i kreuje adresata normy lub recipienta działania ustanowionego tą normą. Natomiast etap trzeci dotyczy tworzenia znaków (1) na mocy swego przyporządkowania do swego nadawcy i do odbiorcy, którego postępowaniem steruje, (2) kieruje uwagę obu na rzeczywistość prawną (3) i normy prawne, jak również (4) spełnia przyporządkowanie rzeczom obrazów literowych rzeczywistości prawnej w kontekście przyczyny, obrazom konstytuującym normy prawne w kontekście skutku - uporządkowanych według konwencji składniowych ${ }^{24}$.

\section{Wnioski}

Z analizy tekstów prawnych wynika, że obrazy rzeczywistości w akcie ustawodawczym są wytworami semantycznymi języka prawnego. Tworzone są przez ustawodawcę dzięki użyciu znaków języka etnicznego do reprezentacji i interpretacji przedmiotów i zjawisk prawnych. Znaki zyskują w języku prawnym znaczenie systemowe przez odniesienie do uniwersalnych pojęć prawnych i prawniczych dzięki zabiegom definicyjnym i lokalizacji kontekstowej. Poza tym w tekście prawnym są znaki, ich odniesienia i relacje między nimi, które zachowały swoje znaczenie $\mathrm{z}$ innych swoistych języków przedmiotowych, w tym z języka powszechnego, i zostały z nich zapożyczone do tekstu prawnego.

W filozofii języka prawnego przyjmuje się rozdzielenie bytu i powinności, zakładając, że prawo nie zajmuje się tym, co jest, lecz tym co powinno być, a powinność prawa i byt społecznej rzeczywistości wzajemnie się wykluczają. Fałszem byłoby jednak twierdzenie, że obrazy konstruowane językiem prawnym nie przedstawiają rzeczywistości prawnej. U podstaw stanowienia prawa znajduje się przecież rzeczywistość społeczna w postaci zachowania się ludzi. Ponadto zwroty powinnościowe ustawodawcy przedstawiają przeżycie psychiczne normodawcy. Materią do wypowiedzi języka prawnego są czyny - są one empirycznymi przesłankami norm prawnych. Doświadczenie życiowe podpowiada wartościowanie zdarzeń. Jednak rzeczywistość ta jest ukształtowana tak, aby odpowiadała celowi nadrzędnemu stanowieniu norm prawnych.

Punktem zaczepienia dla norm prawnych jest rzeczywistość złożona z określonego zachowania się. Możliwy stan rzeczy czerpie materiał z doświadczanej rzeczywistości - wyobrażony możliwy stan rzeczy stanowi całkowicie nową rzeczywistość. W zwrotach powinnościowych rzeczywistość służy do swoistego ujęcia jej przez normę. Powstaje więc stosunek przetwarzający lub wytwarzający języka prawnego do rzeczywistości. Sztuczne twory rzeczywistości języka prawnego nie są zaprzeczeniem faktycznej rzeczywistości społecznej, są natomiast jej przemianowaniem i zdeformowaniem.

\footnotetext{
${ }^{24} \mathrm{~W}$ opracowaniu modelu wykorzystano opis relacji przyczynowo-skutkowych w komunikacji językowej według: Bühler 2004: 25-32
} 
Maria Teresa Lizisowa, Kreowanie obrazów rzeczywistości w akcie ustawodawczym

\section{Źródla}

Kodeks cywilny [k. c.] Ustawa z dnia 23 kwietnia 1964 r. Kodeks cywilny, Dz. U. z dnia 18 maja 1964 r. nr 16 poz. 93.

Kodeks zobowiązań. Rozporządzenie Prezydenta Rzeczypospolitej z dnia 27 października 1933r. Kodeks zobowiązań, Dz. U. z 1933 r. nr 82 poz. 598.

Ustawa prawo bankowe. Ustawa z dnia 29 sierpnia 1997 r. Prawo bankowe, Dz. U. z 1998 r. nr 140, poz. 939.

\section{Bibliografia}

Barthes, Roland. 2000. Mitologie. Przekł. Adam Dziadek. Warszawa: Wydawnictwo KR.

Buczyńska-Garewicz, Hanna. 1980, Świat przez pryzmat znaku. Max Bense, Przekł. Jan Garewicz. PIW: Warszawa.

Bühler, Karl. 2004. Teoria języka. Przekł. Jan Koźbiał. Kraków: Universitas.

Guiraud, Pierre. 1974. Semiologia. Przekł. Stanisław Cichowicz. Warszawa: Wiedza Powszechna.

Krapiec, Mieczysław A. 1985. Język i świat realny. Redakcja Wydawnictw Katolickich: Lublin.

Lizisowa, Maria Teresa. 2006. Tekst - kontekst - interpretacja. W poszukiwaniu semiotyczno-dyskursywnych wzorców konkretyzacji języka. Część pierwsza. Wybrane zagadnienia dyskursu prawnego. Kraków: Collegium Columbinum.

Malinowski, Andrzej. 2006 Polski język prawny. Wybrane zagadnienia. Warszawa: Lexis Nexis.

Mrozowski, Maciej. 2001. Media masowe. Władza, rozrywka $i$ biznes. Wyd. 2 poprawione i uzupełnione. Warszawa: Oficyna Wydawnicza ASPRA-JR.

Ogden, Charles, Kay, Richards, Ivor, Armstrong. 1923. The meaning of meaning. London: Kegan Paul, Trench, Trubner.

Peirce, Charles Sanders. 1931. Wybór pism semiotycznych. Przekł. Ryszard Mirek, Andrzej J. Nowak. Znak - Język - Rzeczywistość. Warszawa: Polskie Towarzystwo Semiotyczne.

de Saussure, Ferdinand. 1961. Kurs językoznawstwa ogólnego. Przekł. Krystyna Kasprzyk. Warszawa: PWN.

Wąsik, Zdzisław. 1997. Systemowe $i$ ekologiczne właściwości języka winterdyscyplinarnych podejściach badawczych. Wrocław: Wydawnictwo Uniwersytetu Wrocławskiego.

Wronkowska, Sławomira. 2007. O cechach języka tekstów prawnych, [w:] Jezyk polskiej legislacji, czyli zrozumiałość przekazu a stosowanie prawa. Warszawa: Kancelaria Senatu.

Wróblewski, Bronisław. 1948. Język prawny i prawniczy. Kraków: Drukarnia Uniwersytetu Jagiellońskiego.

Zieliński, Maciej. 1992. Wypowiedzi dyrektywalne w praktyce językowej, [w:] red. Ziembiński Z., Zieliński M. Dyrektywy i sposób ich wypowiadania, 69-129. Warszawa: Zakład Semiotyki Logucznej Uniwersytetu Warszawskiego.

Zieliński, Maciej. 2002. Wykładnia prawa. Zasady. Reguły. Wskazówki. Warszawa: Lexis Nexis. 
Ziembiński, Zygmunt. 1960. Przepis prawny a norma prawna, RPEiS 1/1960, 105-122. Zirk-Sadowski, Marek. 1984. Rozumienie ocen w języku prawnym. [Acta Universitatis Lodziensis]. Łódź: Wydawnictwo Uniwersytetu Łódzkiego. 
Comparative Legilinguistics 17/2014 